\title{
sciendo
}

\section{Institutional evolution of open and close forms of capitalism - A case of Holland and Japan}

\author{
Jan Krzysztof Solarz ${ }^{1}$ \\ University of Social Sciences, Eucka 11, 05-077 Warszawa, Poland
}

(C) 2019 Jan Krzysztof Solarz. This is an open access article distributed under the Creative Commons AttributionNonCommercial-NoDerivs license (http://creativecommons.org/licenses/by-nc-nd/3.0/

DOI 10.2478/WSBJBF-2019-0008

\begin{abstract}
In the tradition of comparative capitalism, Japan represents a continental banking-oriented system. Holland represents an Anglo-Saxon market system. In Varieties Of Capitalism, Holland and Japan are identified as the same type of Liberal Market Economy (LME) or Coordinated Market Economy (CME). Only a dynamic view presented in this paper explains why Holland and Japan are now LMEs, as they used to be in the years 1868-1930. Holland and Japan used to be CMEs in the years 19101970s. The institutional equilibrium of open capitalism in Holland and close capitalism in Japan can explain periods of economic stagnation in the years 1603-2018.
\end{abstract}

Keywords: Institutional evolutions, Holland, Japan

\section{Introduction}

Considering the concept of Varieties Of Capitalism (VOC), comparative studies on capitalism are usually of static and functional nature. The concept divides the particular countries into the countries of coordinated and liberal capitalism, namely, capitalism in which the key role is performed either by the state or by the market. From this perspective, Japan represents Coordinated Market Economy and Holland is a typical Liberal Market Economy. In a very long and dynamic perspective, Japan represents a close form of capitalism and Holland is an open form of capitalism.

This is a conceptual paper in which I add to the concept of VOC a new dimension: open and close capitalism. The aim of the article is to acknowledge commonly that various types of capitalism undergo evolution, and they change their characteristics. In fact, capitalism has become everyday practice, and is no more just an intellectual multidimensional concept. The key institutions in each capitalism model have followed their long paths of evolution for over 500 years to find their present forms. The division of capitalism models into continental and Anglo-Saxon has been slowly losing its clarity, and numerous hybrid models of capitalism have already started to appear.

Novelty drive from my analysis and overview is Japan as a case of close capitalism. It is intellectual opposition to VOC, in which every type of capitalism is only open capitalism. New reality of global capitalism makes the concept of close capitalism valid.

\footnotetext{
${ }^{1}$ Tel.: 48222587898
}

JKSolarz@san.edu.pl 
A new research field involves a search for the heroes of everyday narration in the particular institutional forms of capitalism. Protestant Dutch traders have been replaced by British engineers, who are being substituted by American entrepreneurs. Economic anthropology allows us to capture the dynamic character and perpetuation of capitalism.

The basic thesis of the article refers to an opinion that institutional equilibrium, which has been shaped for centuries, blocks structural changes in the conditions of closed capitalism, and it is a catalyst for positive adaptive changes in open capitalism. The structure of the article is submitted to the proof of this thesis.

The co-existence of continuity and changeability of capitalism is presented on the example of two countries: Holland and Japan. The choice of these particular countries needs some explanation. Hence, the first part of the article presents the features that allow us to make such a comparison. The first part is focused on the notion categories that are applied in the comparative analysis of capitalism. Among these categories, an important place is taken by the context of institutional governance, which has been historically developed. The second part reminds us about the significance of the reformation for the dissemination of capitalism.

The third part comes as a description of the context for institutional evolution of capitalism in Holland and Japan. In such close environment, a particular role is assigned to nature and to the struggle against the natural elements in both countries. Furthermore, the analysis of the role performed by demographic transformation in the functioning of the financial system is provided. In both countries, methods applied to cover war expenses and their political systems have been significant.

The fourth part presents some milestones of the institutional evolution in both economic systems. The Dutch system refers to open capitalism, which cumulates endogenous institutional changes, whereas the Japanese system refers to closed capitalism, which is reformed from the outside; institutional changes are of exogenous and radical nature.

The fifth part directly confronts open and closed types of capitalism. The abandoned concept of open capitalism forces us to look for the advantages of closed capitalism. Which model of capitalism has got better chances of surviving in the long-term perspective? The article is ended with a discussion of the obtained results, their strong and weak points.

\section{The comparative analysis of capitalism}

Capitalism, as we know it today, comes as an instrument for people to survive their struggle with nature and a way to improve the quality of their lives. The key institutions of capitalism result both from the origin of great ideas of "the invisible hand of the market" or "animal instincts of market participants" and from the origin of a dominating coalition of social and political interests. Obviously, the division into "an idea" and "the interest" is highly arbitrary. It is helpful to differentiate "ours" and "theirs", the endogenous and exogenous character of on-going transformations.

Table 1. The analytical framework applied in the comparative analysis of capitalism

\begin{tabular}{|l|l|l|}
\hline Factors which form capitalism & VOC & Long Time Duration \\
\hline Idea & Anglo-Saxon capitalism & Open capitalism \\
\hline Interest & Continental capitalism & Close capitalism \\
\hline
\end{tabular}

Source: the Author's own study based on (Amable 2017)

The cradle of capitalism was the Merchant Republic of the Netherlands, which transplanted its international tradesupporting institutions to the Parliament of Great Britain. Legal institutions of good quality stimulated the initiation of the Industrial Revolution.

The Industrial Revolution led to extensive divergence in the development of the East and the West. Continental capitalism came as a response of the countries that were catching up with the British Empire. The response incorporated the private pursuit of profits into a broader framework of the national interest.

The developmental sequence of capitalism - from its open to its closed form - has been repeated many times in the current history of capitalism. At present, we are entering the stage of close capitalism domination (Noelke, May 2017).

In order to understand the institutional and evolutional essence of capitalism, it is advisable to compare the development of Holland and Japan over a 500-year period, since the times of Luther and Calvin until present. The 
choice of Holland and Japan is not accidental. At first, it may seem that these two countries are very different from each other-Holland is the cradle of capitalism, whereas Japan represents an example of late capitalism. The discussed countries indicate numerous historical relations and over a 300-years awareness of their existence. They are also the examples of pre-industrial development.

A theoretical framework applied in the article is formed by the institutional evolution and the culture of open capitalism (Holland) and closed capitalism (Japan). The purposeful selection of the countries representing early and late capitalism allows us to confront capitalism that is open to other cultures and capitalism that is closed to strangers.

Simultaneous consideration of cultural and institutional evolution allows us to observe that it is not a linear process. In numerous cases, culture and institutions begin to oscillate, in some other cases they indicate hysteresis. Changes in institutions are stimulated by accreting external effects of the functioning of well-established institutional governance. The dynamic character of changes in culture depends on the demographic transformation of a particular society (Bisin 2017).

An institutional approach allows us to follow mechanisms that enable economic systems to stabilize. At the same time, it also allows us to trace factors that cause disturbance in a system and mechanisms applied to overcome the chaos. Institutions are used to overcome uncertainty, failures of the market and the society. Hence, they are characterized by considerable inertness and their evolution takes a lot of time.

\section{The Reformation as a source of capitalism varieties}

When 500 years ago Luther and Calvin proclaimed a religious schism, it provided ideological foundations for the development of capitalism (Weber). The Reformed Christian Church praised the accumulation of capital, and it ordered its followers to participate in the studies over sacred texts. Following the change in the doctrine, there were some far-reaching changes in practice; the means were allocated from churches and the sacral zone to the facilities of public utility, such as schools and hospitals in the profane zone (Cantoni, Dittmar, Yuchtman 2017). The operational mechanism of the Protestantism was not based on faith but on practical policy of education. On one hand, it was an impulse to establish the Merchant Republic; on the other hand, it formed the foundations for common education, and the dissemination of knowledge capital among citizens of Holland.

Over 300 years ago, having sailed across the endless oceans, the Dutch found Japan. The expansion over the sea was a strategical choice of the Dutch, considering the fact that they were surrounded by the Catholic monarchies. The military leaders of Japan chose the Dutch to be their connection with Western technologies, mainly in the military field. Japanese experience with Portugal, Spain and the Jesuits was not positive. The worshippers of Christ praised human free will, and they contributed to some peasant rebellions in the Japanese Archipelago. In that situation, the enemies of the Jesuits, Spain, Portugal and the Pope became natural allies to Japan, which was seeking isolation from the barbarians.

In the 17th century, two types of economic systems collided. The first system was based on the Confucianism, and the second one on the Reformed Christian thought. Table 2 presents a contrastive comparison of the two economic management systems.

Table 2. The fundamental assumptions: the Confucian economics and Classical Economics

\begin{tabular}{|l|l|l|}
\hline Specification & Confucian Economics & Classical economics \\
\hline 1. Basic aim & Continuity (procreation) & Consumption (existence) \\
\hline 2. Availability of resources & Abundancy (surplus) & Rarity (deficit) \\
\hline 3. Strategy for survival & Diligent work & Acquisition of resources \\
\hline 4. Main motivation & Moral attitude & Property rights \\
\hline 5. Basic institution & Family & Free market \\
\hline 6. Distribution of revenues & Equality (no poverty) & Inequality (poverty) \\
\hline 7. State authority & Meritocratic state & Minimal state \\
\hline 8. Preferable method & Common sense & Theoretical models \\
\hline
\end{tabular}

Source: (Poznański 2017, p. 88)

The main difference consists in the fact that Confucianism is focused on the family and liberalism is focused on the individual. The aim of an individual as a member of a family is the concern about the continuity of the family line or the heritage - not instant gratification, as it is assumed in liberalism. According to Confucianists, 
individuals are motivated by moral responsibility for others, first of all, for their families. In the liberal approach, individuals are driven by the sense of property rights.

The core of Confucianism is harmony, an ability to combine different elements into a whole, which is able to last and to develop. Distinguishing differences fosters their reinforcement-not homogenization. A great man cultivates harmony when differences prevail, whereas an ordinary man levels off differences, losing harmony (Jwa 2017, p. 135).

\section{The institutional context of capitalism evolution}

In a long-term perspective, the institutional context referring to the evolution of capitalism works in favor of institutional convergence of capitalism or its divergence, resignation from one "golden model" of capitalism. In the $19^{\text {th }}$ century, the Industrial Revolution led to the dissemination of "the golden model" of capitalism in the West. In the East, cooperative and labor-consuming techniques were selected, and the Great Divergence could be observed (History 2017). The negative consequences of the Great Divergence were subsequently eliminated by the industrial revolution and globalization. At present, the return to the idea of the Great Divergence can be observed; this time, the negative consequences resulting from the freedom of capital will refer to jobs in the West. An indicator that shows a tendency prevailing in the particular period of time is the supply of global public goods. Recently, it has been possible to observe a systematic decrease in the supply of global public goods and a retreat from the common fight against the global warming and from globalization of economy and science (Bordo M. D., 2017).

\subsection{Institutional governance of the fight against the natural elements}

Both Holland and Japan have extensive networks of institutions, which specialize in the fight against the natural elements. In Holland, it is a system of hydrological installations that allow people to live in the depressed area located below the sea level. The legendary solidarity of the Dutch in the face of the threat posed by water that recedes from the rivers results from the massive loss caused by the water element.

Monsoon rains in Japan could cause deadly mud avalanches if there were not collective rice plantations. The Japanese are exposed to tsunami. Multiple earthquakes cause massive loss and the threats posed by natural disasters are real and present in the social awareness.

In September 1923, Tokyo suffered from such a massive destruction caused by an earthquake and fires that a question appeared whether it would make any sense to reconstruct the city. The phenomenon was interpreted as God's punishment for people's selfishness, immoral conduct and wastefulness.

The fight against the power of nature requires trust towards other networks, systems and organizations, and conformable cooperation of teams. In emergency circumstances, nobody limits the use of ATMs only to their own customers. The settlement of accounts will come after people are brought to safety.

The absolute primacy of the concern about the common safety in the face of fierce natural elements has formed people who are aware of the value of their words and significance of their promises. Being capable of coordinated actions reinforces faith in one's own abilities and develops trust towards fellow citizens.

\subsection{Demographic transformation and capitalism}

The forces of nature directly affected the demographic situation in both countries in the past. The famine in 13151322 and the Black Plague in 1348-1351 resulted in the fact that the population was concentrated mainly in urban areas in the Netherlands. The urbanization in Holland and Japan reached one of the highest levels in Europe at that time (Bateman 2016, p. 26).

Japan applied a very efficient system of birth control, and its population level was stable. At present, the demographic situation in Japan indicates the loss of a demographic bonus and fast aging of the population. The fertility rate of married Japanese women positively varies from the one that is reached in the countries of mature capitalism. The problem is usually related to finding a partner to start a family with. A lot of women in their childbearing age do not have children because they do not have suitable partners. In Japan, fewer than $5 \%$ of children are born out of wedlock. As a result, the fertility in Japan does not allow the country for expanded reproduction of its population.

\subsection{War funding in mature capitalism}

The Merchant Republic of the Netherlands came into existence as a result of dynastic wars and the Protestant rebellions against an unrestrained increase in the number of taxes imposed by the Catholic King of Spain. The 
city-states of Flanders decided to put its own fleet against the oppressors. In a very short time, thanks to the loans from the cities, Holland constructed the largest navy fleet in the world of that time ( Solarz 2017).

At first, Great Britain acted in favor of the Protestants. In the mid-1580s, Queen Elisabeth deployed her land forces to support the Merchant Republic. A century after that, the British political priorities changed, and Holland became the most serious rival to Great Britain in the fight for colonies. As a result, in November 1688, the throne of Great Britain was taken by William of Orange. Moved to the new homeland of their ruler, Dutch institutions started the Industrial Revolution. The Dutch land law was of the key significance, because it was possible to mortgage land or to transform it into capital. The involvement of land property into a complex easement system in favor of rural communities came as a barrier to the development of capitalism in England (Simms, 2017).

\subsection{Capitalism and the type of the state}

The representative of the incessant existence of Japan is its $125^{\text {th }}$ Emperor. The symbol of the ceaseless power and divine origin. Holland is now a constitutional monarchy, and it wishes to be the homeland for descendants of slaves who were once traded by the Dutch. The participation in slave export in 1400-1900 has negatively affected the contemporary level of development of the financial system in the exporter-countries, credit availability for households and credit availability for enterprises. At present, there are no data available on how the import of slaves affected the financial system of the slave importer-countries (Levine, Lin, Xie, 2017).

It is difficult to place Holland and Japan on one scale of state forms. Despite stereotypes, Japan is not a despotic country. An element which integrates that country is a sense of gift and a sense of gratitude for that gift: with regard to parents - for the gift of life, with regard to the Emperor-for the gift of lasting. Holland comes as an example of an open country, which incorporates new citizens. The cost of such openness is the concern about its own identity. Revising history might turn out to be painful for people who are looking for their values there.

At present, we can observe a discourse about a mission of despotic countries. Are they vehicles that transfer the interested parties to material welfare or are they a challenge to democratic countries? (Acemoglu, Robinson 2011). It all depends on the changeable character of the institutional context. If the institutional context remains unchanged from generation to generation, the significance of tradition in our everyday life grows. If the changeability of the discussed context exceeds a certain level, knowledge and wisdom of past generations lose their value, and they cease to be useful in everyday life of the new generations (Giuliano, Nunn 2017).

\section{Milestones in the evolution of the financial systems in Holland and Japan}

The analysis of 500 years of the influence exerted by the Reformation on the shape of institutional governance requires distinguishing some events that are particularly significant for the evolution of capitalism. Such events can be referred to as the milestones.

\subsection{The rise of the capital market (Holland)}

The key to understand the roots of the capital market in Holland is the tax system in the adjacent countries, such as Spain and France. The scale of tax exemption was so immense and the level of tax collection was so low that these countries were not able to fund their war expenses. The Merchant Republic distributed tax liabilities evenly, and it protected its non-resident tax payers.

Figure 1 presents the institutional conditions for the establishment of the stock exchange in Amsterdam.

Figure 1. Institutional conditions for the establishment of the first stock exchange in the world

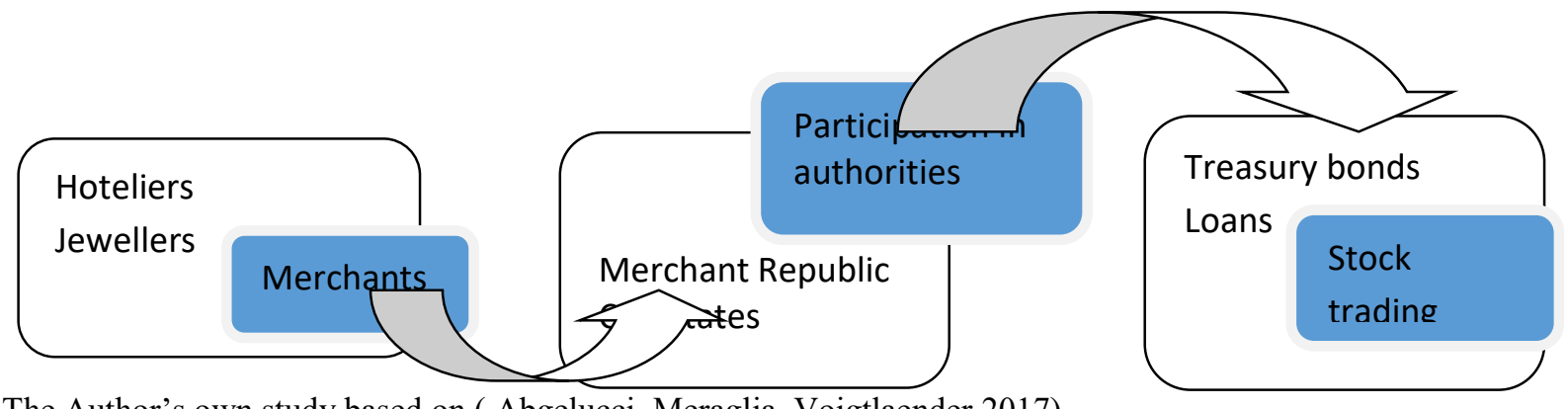

The Author's own study based on ( Abgelucci, Meraglia, Voigtlaender 2017)

\subsection{Tax paid in rice (Japan)}

At the beginning of the 16th century, the military governors of Japan introduced a significant institutional innovation. It was a village tax paid in rice. At that time, in China, taxes were collected from families and paid in silver. This fact made China dependent on the inflow of silver from South America and Japan. Japan purposefully isolated itself from the external world, and it did not use hard money (specie) in its tax system. Rice was supposed to be delivered to the warehouses in Kyoto. Selected by the Bakufu (the military authorities), the method of 
taxation forced the state to invest into the system of roads and canals. The steady tax rate encouraged people to increase the area of agricultural plantations and to increase their work efficiency (Selden 2008).

\subsection{Opening of the Japanese market to the world}

The countries of late capitalism, such as China, Japan and Korea were considered to be blank charts to be filled in accordance with the will of some external forces. In fact, some well-organized and influential groups used to block institutional changes that could have threatened their vital interests (Morck R., Yeung B., 2017, p. 48).

In 1868, the Samurais, who received their compensation in silver for the loss of their feudal privileges, became bankers. Over the first twenty years, after the restoration of the Emperor's power in Japan, an American model of free banking was applied. The chaos in economy and the outflow of silver from the country resulted in the necessity of changing the model that would be followed. The model was taken from the Belgian banks, universal banks, regional and saving banks. Such a structure of banking system has survived until the present day.

Abandoning the market mechanism as a basic regulator of economic governance in Japan was not a one-off sudden event. The Emperor and his followers established model enterprises, they privatized them, and in the $20^{\text {th }}$ century, they finally established free-market economy. Intervention tendencies were observed in the 1930s and 1940s, and they were not any different from what was happening in Holland at that time. After the Second World War, the allies' authorities removed the military factor and the capital that was related to it, opening the way to the rule of government and political parties' bureaucracy (Mrowiec, 2017).

\subsection{External (G-5) imposition of the yen/dollar exchange course}

The Japanese economic miracle broke down as a result of a threat involving the removal of the American protective umbrella, if the surplus gained on the trade with the United States were not brought to the level expected by the United States. Hence, for the second time in its history, Japan was imposed the exchange rate on its currency in relation to the American dollar. In the mid- $19^{\text {th }}$ century, it all ended up with an outflow of silver reserves to the United States; in the mid- $20^{\text {th }}$ century, two decades of economic development were lost as a result of strong deflation expectations.

The change of rules in the middle of the economic game is always a strong shock, which is difficult to overcome. The Mainstream Economics recommends structural changes, such as opening the labor market to immigrants. The Institutional Economics postulates a change in the role of women in Japanese economy. In fact, a new institutional balance should be formed in Japan.

Table 3. Evolution of the institutional governance in Japan

\begin{tabular}{|l|l|l|}
\hline Institutional governance & Institutional balance & Institutional imbalance \\
\hline It fosters economic stagnation & Bakufu & Zaibatsu \\
\hline It fosters economic growth & Keiratsu & $\begin{array}{l}\text { The change in the role of women in } \\
\text { the society }\end{array}$ \\
\hline
\end{tabular}

Source: the Author's own study

The Bakufu is a system of governance in the era of Tokugawa's shogunate. Zaibatsu are great families who have contributed significantly to the restoration of the Emperor's rule. Keiretsu are groups of manufacturers organized around leading production corporations, foreign trade companies and their own banks. The contemporary Japan does not have any institution around which its social governance could be organized. It is planned that this role will be performed by women, who will be active in the labor market, free from their obligations to obey their fathers and husbands.

Table 4. Evolution of the institutional governance in Holland

\begin{tabular}{|l|l|l|}
\hline Institutional governance & Institutional balance & Institutional imbalance \\
\hline It fosters economic stagnation & Dependence on oil extraction & Colonial empire in Indonesia \\
\hline It fosters economic growth & $\begin{array}{l}\text { The Dutch East and West India } \\
\text { Company }\end{array}$ & $\begin{array}{l}\text { Financial institutions important in } \\
\text { the system }\end{array}$ \\
\hline
\end{tabular}

Source: the Author's own study

The welfare of the Dutch was developed by the Dutch East and West India Companies. The VOC operated in the East to the Cape of Good Hope, whereas the WIC operated in Western Africa, North America, Brazil and the Caribbean. Economic stagnation hit Holland during its excessive dependence on the revenue gained on oil extraction. At present, economic safety of Holland directly depends on the condition of its important systemic financial institutions.

Summing up, Figure 2 presents the key points in the institutional evolution in Holland and in Japan. 
Figure 2. The milestones in the institutional evolution of Holland and Japan, from the $17^{\text {th }}$ century to the $21 \mathrm{st}$ century

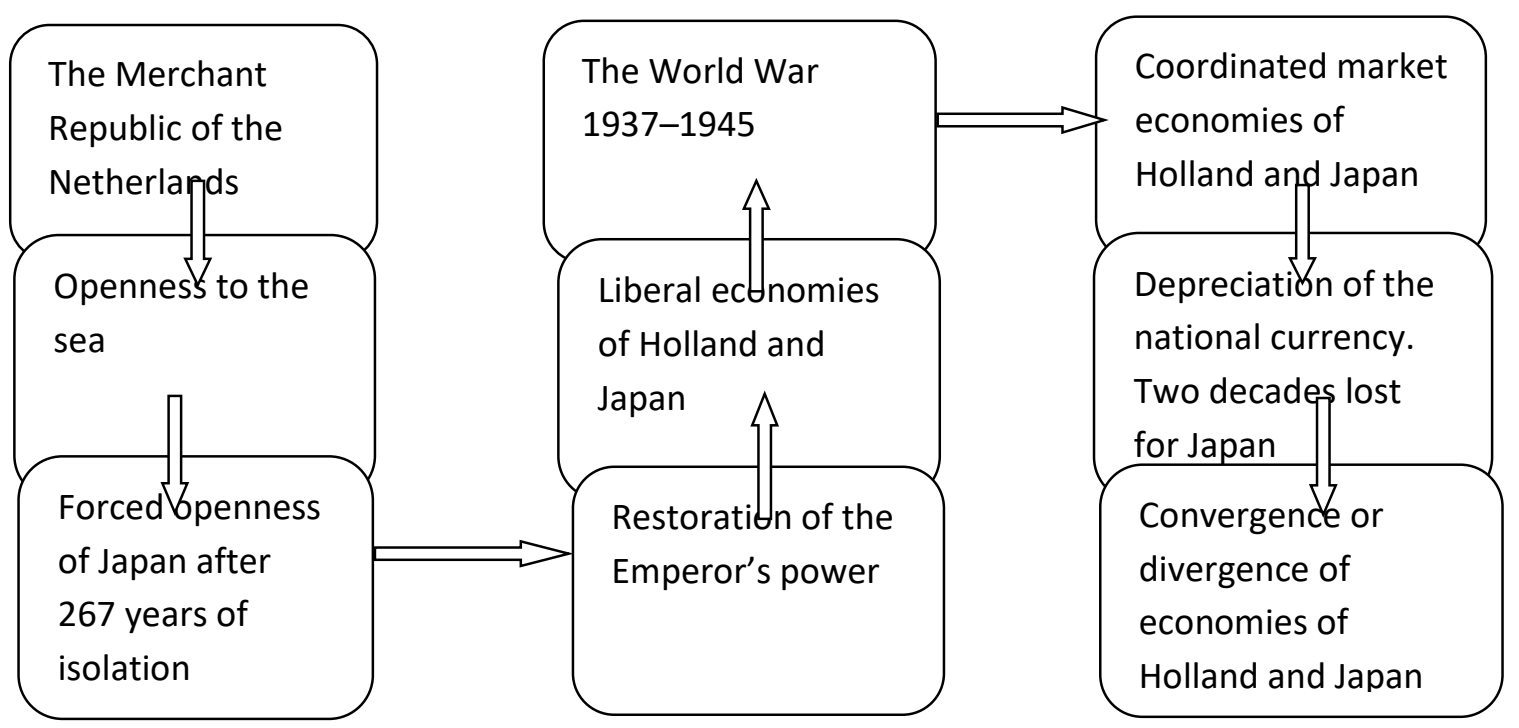

Source: the Author's own study

Once it has been achieved, institutional balance does not guarantee welfare. The fundamental change of the context in which institutions operate results in the fact that institutional balance makes any structural changes in economy very difficult. Institutional governance is not given once for all, it undergoes conscious or forced evolution. Considering Holland, the key institutional innovations have been consciously made, and they have resulted from the country's own assessment of the situation. Most of institutional innovations in Japan have been imposed from the outside, under the foreign pressure. The only exception is the transformation of Zaibatsu into Keiretsu as a result of suggestions made at the lower social circles.

\section{Comparison of the cultures of open capitalism and closed capitalism}

Countries choose the ways of open capitalism or closed capitalism, considering their geographical location and the role of foreign trade in their development. Holland has been stimulated to invest into the quality of its institutions. Japan has purposefully isolated itself from the outside world and has not invested in the improvement of the quality of its public institutions ( Jiao, Wei, 2017).

The analysis of both examples of capitalism assigns the roles of open capitalism to Holland and the roles of closed capitalism to Japan. The choice of the form of capitalism is not given once for all. Whenever the institutional context undergoes any changes, there are opportunities to make a different choice. In their history, Holland and Japan have survived periods dominated by the market financial system and periods dominated by the needs related to funding wars and supporting the country in the attempt to secure its proper position in the world.

So far, economists have not paid much attention to financial intermediation, treating it as a synonym for capital allocation. At the end of the $20^{\text {th }}$ century, the network of relations between the factual and financial spheres of economic development gained more attention (Financial 2017). After the global financial crisis, it was assumed that the financial sector suffered degeneration, and it came down to taking credits for work performed by others. It is still considered that the financial sector positively affects economic growth. Economic growth and microeconomic risk are two sides of the same coin (Popov, 2017, p. 54). At present, in the institutional development of capitalism, it is possible to distinguish the organizational, systemic and network stages.

\subsection{Institutions are organizations}

At the beginning of the 17th century, three joint-stock companies appeared, two of them being East India enterprises and one West India company. The West India Company operated in Brazil and North America. There were two hundred clergymen in that Dutch company, employed full-time to lead their missionary tasks. The company went bankrupt in the end.

The Dutch East India Company operated in Indonesia, taking over pepper trade from the Portuguese. While sailing to the Dutch colonies, it was necessary to call at Japanese ports. In that way, a permanent connection was 
established in the cooperation with Japan. The company actually held the monopole for the trade with Japaneven the Chinese needed Dutch intermediation to trade copper and silver.

Having established their own company, the British spread out all over India.

Institutional innovations have changed global trade, and they have democratized the contact with distant continents.

\subsection{Institutions are systems}

The Dutch financial system was shaped on the basis of the first stock exchange in the world, where the shares of the East India Company were the only shares traded there at the beginning. Then other commodities appeared along with more advanced financial instruments.

The financial system in Holland was always subdued to the national interest. Holland represents a coordinated type of economy, which is subordinated to the economic policy of the state. Also, the financial system of Japan has been developed to meet the requirements of the state. During the free-market period, the capital market was developed and share trading was promoted. However, military requirements did not allow the stock exchangeoriented financial system to become well-established.

In the 1980s and 1990s, Japan made an attempt at returning to the financial system, which would be oriented towards the capital market. However, the attempt failed. Then there was an attempt at forcing Japanese citizens to close their accounts at the Post Bank. It was expected that households would decide to diversify their investment portfolios. It never happened though. The habit of keeping away from risky financial assets was again manifested. Japanese women have always managed household finance, and they do not accept playing the stock market. Risk culture is usually developed over the centuries and the lack of willingness to take risk is a difficult habit to change.

\subsection{Institutions are networks}

The traditional perception of institutions cuts actors' connections with others. It is a mechanism that imposes socially expected behavior. The modern approach towards institutions, viewed as links in the network of interactions rooting institutions in culture, provides them with internal dynamics (Ferguson 2017).

The diffusion of institutions of market economy takes place inside the network of existing institutions: in Holland - in merchants and hoteliers' guilds; in Japan - military governments and the cult of a great family. The local and political conditions perform a significant role in the diffusion of new institutions (Comino, Galasso, Graziano, 2017, p. 3).

In 1980s, the pressure to open the Japanese market resulted in actions that were intended to lead manufacturing and entrepreneurship outside Japan. At present, Japanese cars are more and more often produced outside Japan. The technical thought and corporate culture are still Japanese, but other activities are outsourced in various parts of the world.

It is often argued that Japan has run into excessive debts. The government debt is now twice the amount of its GDP. It is a lot, but it still does not pose any danger to the financial safety of the state. Only $5 \%$ of that debt remains in foreign hands. Grateful for the continuation of their national community, the Japanese are not going to abandon other citizens in trouble. The national strategy for financial education explicitly states the patriotic obligation to purchase treasury bonds (Solarz, 2017). The fundamental difference in the institutional governance of Holland and of Japan refers to the character of their institutional networks.

Table 5. Comparison of the open and closed forms of capitalism

\begin{tabular}{|l|l|l|}
\hline Key institutions & Open capitalism (Dutch) & Closed capitalism (Japanese) \\
\hline Organizations & The Bank of Amsterdam & $\begin{array}{l}\text { Zaibatsu } \\
\text { Keiretsu }\end{array}$ \\
\hline Systems & $\begin{array}{l}\text { Stock exchange (transactional } \\
\text { banking) }\end{array}$ & Banking (relational banking) \\
\hline networks & Inclusive & Exclusive \\
\hline
\end{tabular}

Source: the Author's own study

The Bank of Amsterdam comes as a successful copy of an institution, which was once effective in the Republic of Venice, where the city-state bank used to finance sea voyages organized by merchants. The city-state authorities used to guarantee credits taken for sea voyages with their personal property. The symbiosis of merchants and citystate authorities allows us to understand common interest in a better way.

The Bank of Amsterdam guaranteed the stability of the purchasing power of the common and abstract currency, the guilder. Its task was to facilitate the settlement of transactions entered by the citizens of the Merchant Republic. It was a prototype of a central bank.

Attempts at copying solutions, which work in one institutional context, may fail under different conditions, as for example, an attempt made at shifting the capital market to the center of the Japanese financial world. It did not 
work there. Similarly, attempts at transplanting Dutch flexible forms of employment seem to have failed. The cultural barrier becomes apparent because no one knows what kind of social distance is between them and their interlocutors whose employment status is not clear. We do not know, which courtesy form out of 12 possible ones should be used in a conversation with a person who is employed based on a fix-term contract. Some more hope can be pinned on the development of cooperative work. The social status of a cooperative entity members is high and their morale - even higher.

\section{Conclusions}

A comparative analysis of the institutional evolution of the financial systems in Holland and in Japan brings us to the point where it is necessary to ask whether the convergence of these systems and their contexts is growing or whether the time of divergence is coming soon.

Such a question can be answered in two ways. Undoubtedly, the experience of the last 500 years indicates that these were the years of convergence. It is indicated that the tendency towards convergence will still prevail. What we can observe is only a temporary break in this inevitable process.

However, a critical scientist may recognize some weak indications of a tendency towards divergence. Referred to as FinTech, technical revolution, artificial intelligence and big data make humanity disperse in time and space into points, personified micro-worlds of individuals. Their free will is replaced by algorithms, which make them act in a controlled way in favor of sellers' best interests.

A unit that integrates the world of finance is intergenerational transfer. If new generations live in worse conditions than their predecessors, they will try to question the existing institutional governance. Undoubtedly, new generations have fewer chances to live in better conditions than their parents. In Japan, it is strictly related to the problems with finding a partner for expanded reproduction; in Holland, with feeling proud of the colonial past of the country (Theorizing 2018).

There aren't any reliable proofs that the process of institutional divergence has been already started. It is possible that complexity cannot be recognized through institutional innovations. Complexity requires new instruments to be coped with. Creators of institutional governance in capitalism in Poland must face a dilemma whether they should follow the path of open (global) capitalism or closed (national) capitalism.

\section{References}

Acemoglu D., Robinson J. A. (2017), The Emergence of Weak, Despotic and Inclusive States, NBER Working Paper 22657

Amable B. (2017), Structural Crisis and Institutional Change in Modern Capitalism. French Capitalism in Transition, Oxford University Press

Angelucci C., Meraglia S. Voigtlaender N. (2017), The Medieval Roots of Inclusive Institutions: From the Norman Conquest of England to the Great Reform Act, NBER Working Paper 23606

Bateman V. N. (2016), Markets and growth In early modern Europe, Routledge

Bisin A. (2017), On the joint evolution of culture and institutions, NBER Working Paper 23375

Bordo M. D. (2017), The second era of globalization is not yet over: An historical perspective, NBER Working Paper 23786

Cantoni D., Dittmar J., Yuchtman N.(2017), Religious competition and reallocation: The political economy of secularization in the protestant reformation, NBER Working Paper 23934

Comino S., Galasso A., Graziano C., (2017), The Diffusion of New Institutions: Evidence from renaissance Venice's patent system, NBER Working Paper 24118

Ferguson N. (2017), The Square and the Tower. Networks, Hierarchies and the Struggle for Global Power, Allen Lane

Financial Systems and Economic Growth. Credit, Crises, and Regulation from the $19^{\text {th }}$ Century to the Present, eds. P. L. Rousseau, P. Wachtel (2017), Cambridge University Press

Giuliano P., Nunn N., (2017), Understanding cultural persistence and Change, NBER Working Paper 23617

History of the Future of Economic Growth. Historical Roots of Current Debates on Sustainable Degrowth, Eds. Iris Browy, Matthias Schmelzer, Routledge,

Horda T. (2017), Pax Japonica. The Resurrection of Japan, Lid Pub.

Jiao Y., Wei S. J. (2017), Intrinsic openness and endogenous institutional quality, NBER Working Paper 24052

Jevine R., Lin C., Xie W. (2017), The origins of financial development: how the African slave trade continues to influence modern finance, NBER Working Paper 23800

Morck R., Yeung B. ( 2017), East Asian financial and economic development, NBER Working Paper 23845 
Mrowiec M. (2017), Austriacka Szkoła Ekonomiczna. Jak może pomóc wyjaśnić stagnację gospodarki Japonii, PWN

Noelke A., May C. (2017), Comparative Capitalism Research in Times of the Financialization Crisis: From an Inter-national to an Inter-temporal Study of Economic Institutions, Goethe University

Popov A. (2017), Evidence on finance and economic growth, European Central Bank Working Paper 2125

Poznański K. (2017), Ekonomia jako etyka: podejście konfucjańskie, w Etyka i ekonomia. W stronę nowego paradygmatu, ed. E.Mączyńska, J.Sójka, PTE

Selden M. (2008), Center and Periphery in East Asia in Three Epochs, Journal of Northeast Asian History, Vol. 5 No 1, p. 5-20

Simms B. (2017), Britain's Europe. A Thousand Years of Conflict and Cooperation, Penguin Books

Solarz J. K. (2017), Ewolucja instytucjonalna systemów finansowych w Holandii $i$ w Japonii, edu-Libri

Solarz J. K. (2017), Financial education In Japan, Journal of Insurance, Financial Markets \& Consumer Protection No 25, p. 117-127

Theorizing, Analyzing, and Transforming Capitalism(2018), eds. Tae-Hee Jo, Lynne Chester, Carlo d'Ippoliti, Routledge 